\title{
Vitaly Grigorevsky's Contribution to the Development of International Cooperation in Photometric Studies of Artificial Earth Satellites
}

\author{
Iryna Hrushytska \\ Odessa National Polytechnic University \\ Shevchenka Ave. 1 \\ Odessa 65044, Ukraine \\ Email: ira1973gr@gmail.com
}

\begin{abstract}
This article highlights the participation of the Ukrainian scientist, Professor Vitaly Mikhailovich Grigorevsky, doctor of physical and mathematical sciences, and representative of the scientific school of Vladimir Platonovich Tsesevich, in the organization and development of international cooperative partnership in the field of satellite astronomy and photometric studies of artificial satellites of the Earth. The activity of the scientist in the coordination of scientific research of the countries of Eastern Europe in 1965-1973 under the SPIN program, carried out under the auspices of the Astronomical Council of the USSR Academy of Sciences, is discussed. The article explores the main forms of Grigorevsky's scientific cooperation with the world's leading experts in the field of satellite astronomy — the British scientist Desmond King-Hele, the Czech astronomer František Link, Hungarian researchers Iván Almár and D. Toth, and others. Also, the achievements of the Latvian researchers Māris Ābele and Kasimirs Lapushka in the creation of photographic cameras of surveillance of satellites are analysed.
\end{abstract}

Keywords: artificial Earth satellites, Eastern Europe, multilateral international cooperation, photometric observations, SPIN

Professor Vitaly Mikhailovich Grigorevsky (1930-1981), doctor of physical and mathematical sciences, was a Ukrainian scientist who worked in the field of classical astronomy, satellite astronomy and in the application of computers to solve applied problems. He was a representative of the scientific school of Professor Vladimir Platonovich Tsesevich, doctor of physical and mathematical 
sciences, and a corresponding member of the Academy of Sciences (AS) of the USSR. Grigorevsky graduated from the Faculty of Physics and Mathematics (in 1954 ) and the graduate school at Odessa University with a degree in astronomy (1960). He worked at the universities of Odessa (1955-1957 and 1970-1976) and Chisinau (1960-1970), the Odessa Technological Institute of the Food Industry (1976-1981), was a member of the International Astronomical Union (IAU), the Committee on Space Research (COSPAR), and the Commission on multilateral scientific cooperation between the Academy of Sciences of socialist countries (Archive of ONAFT, F. 4/1-L/1981.1659, p. 3). With the advent of the space age, Grigorevsky became one of the initiators of photometric observations of artificial Earth satellites (AES) (Masevich \& Slovokhotova, 1967, p. 48).

Historiography concerning the analysis of Professor Grigorevsky's scientific activities is not very extensive for the reason that the scientist was engaged in fundamental and applied research in defense and space industries. However, in the Soviet Union, such research and development work was classified as the so-called "special topics", access to it was restricted based on varying grades of secrecy (Sukhoterina et al., 2013, p. 136). This became an objective reason for the lack of Soviet historiography related to the activities of Ukrainian scientists, in particular Vitaly Grigorevsky, who participated in international cooperation in the field of satellite astronomy. Some information about Grigorevsky's such activities can be found in works published already during the period of independence in Ukraine. Besides, Vitaly Grigorevsky died early, at the age of 51, at the very peak of his scientific career, which also left its mark and required time for an objective assessment of his scientific activities.

The first article about Grigorevsky appeared in 1995 in the memoirs of his close friend and colleague O. E. Mandel and was included in the collection Pages of the History of Astronomy in Odessa, edited by V. G. Karetnikov (Mandel, 1995). Exactly ten years later, Karetnikov wrote Vitaly Grigorevsky's biographical overview in a 4-volume reference book on the history of Odessa University, Professors of the Odessa (Novorossiisk) University, based on the memoirs of Vitalt Grigorevsky's wife and co-author V. A. Vorobyova (Karetnikov, 2005). Grigorevsky's personality captured the attention of the author of this study while working on an article on the establishment of photometric studies of satellites in Ukraine (Hrushytska, 2018). In addition, the research work was carried out in the archives of Odessa, and the archives of the official publication of the USSR Academy of Sciences-the Bulletin of the USSR Academy of Sciences. The work resulted in interesting factual material, revealing and detailing certain aspects of the scientist's scientific activity, which 
makes it possible to revise Grigorevsky's role in the development of international cooperation in the first decades of space exploration. In 2019, a special publication dedicated to the life and work of Vitaly Mikhailovich Grigorevsky was prepared, which examines and analyses the main periods of the scientist's life in detail and identifies the main directions of his scientific research (Hrushytska, 2019).

The aim of this study is to highlight Grigorevsky's participation and coordination activities in international cooperative research on satellite photometry.

International cooperation has always played a leading role in space exploration. The planetary nature of most of the observed phenomena and the great practical importance of the obtained results for humanity have necessitated wide international cooperation in this area. Since the launch of the first Soviet satellite on 4 October 1957, in accordance with the program of the International Geophysical Year, a network of special observation stations has been created, a peculiar "satellite service", the purpose of which was to forecast satellite motion for the coming days.

For this purpose, it was necessary to carry out regular observations in different places of the Earth and to report the results of these observations to the computer centre in the shortest possible time. In the USSR, 70 visual satellite observation stations were continuously operating; in the USA, the Moonwatch system covered more than 100 stations; in Japan, 59 stations were observed; in the Netherlands-18; in China-14; in Czechoslovakia-13; in Poland-10; and in the German Democratic Republic (GDR)—8 (Masevich, 1959).

In the USSR, international cooperation was carried out both on a bilateral basis and through various forms of regional and multilateral cooperation, as well as within the framework of international organizations. The Soviet Union cooperated, above all, with countries of the socialist camp—Bulgaria, Hungary, the German Democratic Republic (GDR), Cuba, Mongolia, Poland, Romania, Czechoslovakia. The collaboration of scientists in most of these countries began immediately after the launch of the first satellite. Each country has contributed to the AES observations and to solving important geodetic and geophysical tasks. The accumulated experience allowed a transition to the multilateral cooperation, which opened up the possibility of implementing more complex research programs that required the collective work of observers in many countries. Except for the scholars from socialist states, scientists from Italy, Finland, France, the Federal Republic of Germany and other countries took part in some of these programs (Blagonravov \& Vereshchagin, 1967, p. 7). 
On March 14-17, 1962, at a meeting in Warsaw, as a result of an agreement between the academies of sciences (AS) of many socialist countries, a decision was made to create a Commission on multilateral cooperation in the matter of 'Optical Observations of AES' (Erpylev, 1963, p. 75). At the suggestion of Polish scientists in 1965, it was renamed the Commission on the matter of 'Scientific research using AES observations'. The commission was entrusted to the Astronomical Council of the USSR Academy of Sciences. On 27 November 1962, the first coordination meeting of the Commission was held in Leningrad. The meeting was attended by representatives of Bulgaria, Hungary, East Germany, Mongolia, Poland, Romania, the Soviet Union and Czechoslovakia. In accordance with the recommendations of this meeting, the Commission held working sessions at least once a year in different countries, usually to coincide with the scientific conferences of satellite observers. The academies of sciences of Bulgaria, Hungary, Vietnam, East Germany, Mongolia, Poland, Romania, the USSR and Czechoslovakia conducted joint satellite observations according to a single program. There was an exchange of observation results and other materials obtained in the course of collective work. The cooperating countries published the results of their joint work in the international almanac Observations of Artificial Earth Satellites, the first issue of which was presented at a meeting in Warsaw on 8 June 1963 and summed up the work of 5 years since the launch of the first satellite in the history of humankind. It was decided that the almanac will be published annually, alternately by all the cooperating countries. Chinese scientists attended the meeting as observers. (Erpylev, 1963, p. 76)

The multilateral scientific cooperation was carried out on the following issues:

- Visual satellite tracking for the purposes of the ephemeris service (coordinated by the USSR Academy of Sciences);

- Visual observation of low-flying satellites to study temporal variations in atmospheric density (INTEROBS program, coordinated by the Hungarian Academy of Sciences);

- Synchronous photographic satellite tracking for triangulation (coordinated by the Astronomical Council of the USSR Academy of Sciences);

- Development and improvement of equipment used for satellite tracking (Academies of Sciences of the GDR, Poland, the Soviet Union and Czechoslovakia);

- Photometric satellite observation (coordinated by the Academy of Sciences of the USSR and Czechoslovakia); 
- Calculation of satellite orbital elements, research in the field of satellite geodesy and geophysics, etc. (Masevich \& Slovokhotova, 1967)

In 1970, the entire program of space research carried out as part of the cooperation of the socialist countries was called 'Intercosmos' (Petrov\& Kroshkin, 1972, p. 76).

Unlike ordinary celestial bodies, the motion of artificial Earth satellites is very much influenced by the Earth's atmosphere. It is different at different points in the orbit and varies very irregularly. The usual methods of celestial mechanics for calculating the orbits of artificial Earth satellites were not sufficient. The scientists faced the task of creating an exact analytical theory of satellite motion, designed to solve geophysical problems without which it was impossible to give accurate predictions of their positions over a long time (Masevich, 1959). To create a theory of satellite motion, it was necessary, first of all, to solve the most difficult geophysical problem of a comprehensive study of the Earth's atmosphere.

Photometric observations of artificial Earth satellites, carried out in the USSR since 1958 with Vitaly Grigorevsky as one of the initiators, showed that the period of rotation of the satellite is affected by changes occurring in near-Earth space. These changes opened the most promising perspective for a wide variety of studies both in the field of satellite dynamics and the properties of spacecraft themselves and in studying the properties of their environment (Mandel, 1995, p. 54).

Grigorevsky's research showed the dependence of the observed changes in the period of rotation of the satellite on changes in the state of the Earth's atmosphere and magnetic field (Grigorevsky, 1960; 1961), proving the connection between changes in the period of the satellite's rotation around the Earth and the manifestation of solar activity. A significant increase in the deceleration of the satellite's rotation was noted immediately after strong chromospheric flares on the Sun and subsequent geomagnetic disturbances; this increase was synchronous with similar changes in the periods of rotation of satellites around the Earth (Grigorevsky, 1967).

Vitaly Grigorevsky, along with colleagues, among whom were his graduate students-M. Ya. Tovadrovs (Egypt), B. B. Baghos (Egypt), S. Ya. Kolesnik (Odessa, Ukraine), became the author of significant works in the field of artificial Earth satellite photometry, concerning the determination of the density of the Earth's atmosphere by deceleration of satellite rotation (Grigorevsky \& 
Bukhbinder, 1967; Tovadrovs et al., 1970; Beletsky et al., 1975) and the effect of the Earth's magnetic field on the nature of satellite motion (Shmelev et al., 1969; 1973).

With the advent of military satellites, the problem of their identification and control of orbit parameters arose. As part of the work on the creation of fundamentally new technical means for obtaining non-coordinate information about space objects necessary for their recognition, Vitaly Grigorevsky developed algorithms for processing non-coordinate optical information obtained on the basis of AES photometric observations ('Kak my uchilis...', 2002; Mandel, 1995).

The 1967 and 1968 materials of Grigorevsky's research were exhibited at the Exhibition of Achievements of National Economy of the USSR in the pavilion 'Cosmos' and were awarded a bronze medal (Archive of ONAFT, F. 4/1L/1981.1659, p. 22).

In the years 1965-1973, on behalf of the Astronomical Council of the USSR Academy of Sciences, Grigorevsky headed international cooperative work on artificial Earth satellite photometry, the purpose of which was to study the factors affecting the change in the period of rotation of a satellite from photometric observations-the SPIN program (Archive of ONAFT, F. 4/1-L/1981.1659, p. 25).

At a meeting in Riga on February 1-5, 1965, Vitaly Grigorevsky made a report on the study of the relationship between the change in the period of rotation of the satellite and solar activity from observations of changes in the brightness of satellites. This forum was attended by representatives of Bulgaria, Hungary, East Germany, Poland, Romania, the USSR, and Czechoslovakia. Specialists from Italy, Finland and Sweden, countries that took actively part in the joint work, were also invited. Particular attention was paid to basic visual observations for studying short-term changes in atmospheric density (INTEROBS program, coordinated by M. Ill, Hungary) (Kasimenko \& Lurie, 1965).

It was not by chance that Riga was chosen as the venue for this international forum. Latvian researchers at that time (Māris Ābele and Kasimirs Lapushka) already had experience in satellite observations and successes in creating photographic surveillance cameras for artificial Earth satellites. In 1965, at the photographic tracking Station No. 1084, Riga (head Kasimirs Lapushka), an AFU-75 camera with a focal length of the lens of $736 \mathrm{~mm}$ and $\mathrm{d}=210 \mathrm{~mm}$ was 
constructed (Masevich \& Slovokhotova, 1967, pp. 47, 50). The camera used a seven-lens type 'Uranus- $16^{\prime} \mathrm{d} / \mathrm{f}=1: 3.5$. The field was $10^{\circ} \times 14^{\circ}$. Photographing was carried out on a $190 \mathrm{~mm}$ wide film. A guide telescope was mounted on the camera. The entire camera was installed on a special equatorial platform, which was a device for tracking the daily rotation of stars for $2-3$ minutes. Such original design was not on any of the existing "satellite cameras" at that time. Four-axis mounting of the camera on the platform made it possible to track the satellite along an arc of a small circle. The camera allowed photographing satellites from the 3rd to the 10th magnitude. AFU-75 cameras worked at Soviet stations in Riga, Uzhgorod, Zvenigorod and Yuzhno-Sakhalinsk. They were also installed at stations in Ondřejov (Czechoslovakia), Sofia (Bulgaria), Ulan Bator (Mongolia), Bayeux (Hungary), Cuba, the United Arab Republic, Somalia, Japan and Mirny (Antarctica). All these stations participated in international satellite surveying programs (Masevich \& Lozinsky, 1970, p. 42).

In particular, starting in 1966, the stations in Riga and Uzhgorod regularly participated in international observations of American active geodetic satellites of the Geos type, together with stations in Western Europe, Asia and the United States under the program of the Smithsonian Observatory of the United States. In 1966, at the Riga station (observer Lapushka), 29 photos of scintillations of the Geos satellite were obtained, 11 of which were synchronized with a number of stations in Western Europe (Masevich \& Slovokhotova, 1967, p. 9; Masevich $\&$ Lozinsky, 1970, p. 42). Soviet-African stations in the United Arab Republic and Somalia, as well as stations on the territory of the Soviet Union in Riga, Uzhgorod and Zvenigorod, participated in the international satellite observation session 'Pageos' in late 1968 and early 1969 together with the stations in France, England, Greece, Spain, and the USA under the program of the National Geographic Institute of France. These synchronous observations were intended to clarify the shape of the Earth using the 'geodesic triangulation' of the satellite (Galperin \& Vedeshin, 1972, p. 87).

At a meeting of the Commission on Multilateral Cooperation, which was held in Uzhgorod on May 12-14, 1967, the SPIN program coordinator Vitaly Grigorevsky summed up the results of the 1966 observations on a program providing photometric studies of satellite rotation to study atmospheric density fluctuations in connection with changes in solar activity (Slovokhotova, 1967, p. 98). The same year, presenting the main research results of the SPIN program at the anniversary meeting on the occasion of the 10th anniversary of artificial Earth satellite research, Grigorevsky set the following tasks for its participants: 
a) To obtain good observational materials, conduct a large number of continuous observations of two or three satellites at different altitudes, provided that the objects and observation intervals are the same as in the INTEROBS program;

b) Theoretically study the deceleration of the satellite's rotation under the influence of electromagnetic, aerodynamic and other factors, under various conditions, in particular, when the actual influencing factors change and when the satellite's orientation changes;

c) Statistically investigate changes in the rotation period depending on changes in solar activity and seasonal changes in the Earth's atmosphere (Grigorevsky, 1967).

The same forum approved the intention to join the SPIN program of the Heluan Observatory, since the weather conditions in the United Arab Republic (the official name of Egypt until 1971) allowed to conduct photometric observations throughout the year (Grigorevsky, 1967, p. 36) and made it possible to investigate seasonal effects on satellite rotation speed.

At the invitation of the Ministry of Scientific Research of the Arab Republic of Egypt, Grigorevsky traveled twice to Egypt to give lectures on artificial Earth satellite photometry at Cairo University. The first official business trip was one month long and took place in April 1967, and the second lasted for four months from January to April 1969. He also supervised two graduate students who worked in this field. In January 1971, both graduate students successfully defended their master's theses (Archive of ONAFT, F. 4/1-L/1981.1659, pp. 4, 22).

As the coordinator of the international SPIN program, Vitaly Grigorevsky travelled to Hungary in October 1965, East Germany in October 1966, and Poland in October 1967 and September 1973, where he participated in scientific conferences. In March 1977, he visited Portugal and France (Archive of the Odessa National Academy of Food Technologies, p. 4). With his good command of English, French and German (Archive of ONAFT, F. 4/1-L/1981.1659, p. 4), Grigorevsky carried out extensive correspondence with many astronomers from other countries, which was the reason, according to the memoirs of his colleagues, for his occasional troubles in relations with the First Department: after all, he was involved in classified topics (Mandel, 1995). Thus, in the difficult conditions of the communist totalitarian regime, which took on increasingly harsh forms, the Ukrainian scientist was at the forefront of the Euro-integration processes in the development of Ukrainian science. While on a business trip in Hungary from 25 October to 4 November 1970, Vitaly Grigorevsky, together with the 
coordinator of the network of Hungarian observation stations of the AES, Director of Station no. 1111 (Budapest) Iván Almár became acquainted with the Hungarian programs for the study of the properties of the upper atmosphere of the Earth. The forms of participation of the Hungarian stations in the SPIN program were discussed, and an agreement was reached on the observation of this program of stations in Bahia and Szombathely (State Archives of Odessa Region, F. p-1438.14.201, pp. 97-100).

With the staff of the station in Szombathely (head Gyula Thoth), in the program of observations, which was designated the 'Pageos AES' and monitored synchronously with the stations of Lyon (France) and Sidzheyov (Czechoslovakia), Grigorevsky was familiar with all aspects of their work. From the head of the station, information was received in English on the photometric characteristics of a number of satellites for use in the work process under the SPIN program. This was made possible by the fact that by 1970, all Hungarian stations had established close contact with the SLOUGH Coordination Center in England and received the ephemeris data of virtually any object, including those for which ephemeris could not be obtained by researchers in the USSR. At Grigorevsky's request, Iván Almár handed over to the Ukrainian researcher the use of the program in the ALGOL-60 language, following A. I. Lozinski's method for determining the orbital period of satellites. The program was drawn up by E. Illes-an employee of the Budapest station (State Archives of Odessa Region, F. p-1438.14.201, p. 99).

On 30 October 1970, Vitaly Grigorevsky made a report at a meeting of the Hungarian Astronautical Society on photometric observations of the AES and investigated the relationship of variations in solar activity with changes in the density of the Earth's atmosphere (State Archives of Odessa Region, F. p-1438.14.201, p. 98).

An article by Grigorevsky, published in December 1970, in collaboration with the world's leading experts in satellite astronomy, is dedicated to considering the scientific use of photometric observations of the AES (Smith et al., 1970). Among the co-authors were the prominent British scientist Desmond King-Hele and the Czech astronomer František Link.

Desmond King-Hele is widely known for the theoretical processing of satellite observations to determine the density of the atmosphere and the external gravitational field of the Earth (King-Hele, 1968, pp. 5-6). Starting with the launch of the first satellite in October 1957, he continued to carry out visual 
observations of artificial celestial bodies, studied changes in their orbits and organized regular visual satellite service from amateur observers in England. Since that time, King-Hele led the ephemeris satellite service of England. (KingHele, 1963, p. 6) He was the first to discover and study variations in the density of the atmosphere depending on the activity of the Sun. Desmond King-Hele has the most reliable definitions of higher-order terms in the expression for the Earth's gravitational potential. For these outstanding works, he was elected a full member of the Royal Society of England in 1966 (King-Hele, 1968, pp. 5-6).

František Link, director of the Ondřejov Observatory in 1948-1953, was one of the pioneers of Czech astronomy. Link was one of the first to determine the amount of atmospheric ozone and proposed a twilight measurement method for the AES. He maintained close relations with French astronomers throughout his career. He worked at the observatories in Lyon and at Pique du Midi. Two years after the Soviet invasion of Czechoslovakia in 1968, he emigrated to Paris, where he worked at the Observatory of Paris until his death in 1984 (Ceplecha et al., 2006).

Thus, most of the achievements in space exploration would not have been possible without international cooperation, which is a powerful tool for the development of space activities on a global scale. It allows us to increase achievements in space, expand the boundaries of research and use of outer space while opening up new directions in the field of scientific and technical innovation and combining the efforts of scientists from different countries to explore space for the benefit of humanity.

Vitaly Grigorevsky put a lot of effort into developing international cooperation in the field of photometric observations of artificial Earth satellites. Owing to his scientific work and good social contacts, acting as coordinator of the SPIN program, Grigorevsky made a significant contribution to the organization and development of satellites' photometric observations in many countries of Eastern Europe and contributed to the entry of Ukrainian science into the European research space long before the country gained independence. On the eve of the scientist's 90th anniversary, which will be celebrated in 2020, the analysis of his scientific heritage is of particular importance for understanding the development processes in the science of astronomy in the world. 
Vitaly Grigorevsky's Contribution to the Development of International Cooperation in Photometric Studies of Artificial Earth Satellites

\section{References}

Archive of ONAFT, 'Vitaly Grigorevsky,' F. 4/1-L/1981.1659, Archive of the Odessa National Academy of Food Technologies.

Beletsky, V. V.; Grigorevsky, V. M. \& Kolesnik, S. Ya. (1975), 'Vrashatelnoe dvizhenie ISZ i opredelenie plotnosti atmosfery' [Rotational motion of the AES and determination of atmospheric density], Preprint Inst. Prikl. Mat., no. 7.

Blagonravov, A. A. \& Vereshchagin, V. S. (1967), 'Sovetskii Soyuz i mezhdunarodnoe sotrudnichestvo v mirnom osvoenii kosmosa' [The Soviet Union and international cooperation in the peaceful exploration of outer space], Zemlya i vselennaya, no. 1, pp. $1-10$.

Ceplecha, Zd.; Bumba, V.; Grygar, J. \& Olivová, Ja. (2006), 'Sté jubileum českého astronoma Františka Linka,' Česká astronomická společnost. Retrieved from https://www.astro.cz/clanky/ostatni/ste-jubileum-ceskeho-astronoma-frantiskalinka.html [accessed 15 Aug 2019]

Erpylev, N. P. (1963), 'Soveshanie Komissii po probleme "Opticheskie nablyudeniya iskusstvennyh sputnikov Zemli"' [Commission meeting on the issue of "Optical observations of artificial Earth satellites"], Vestnik AN, no. 9, pp. 75-76.

Galperin, Yu. I. \& Vedeshin, L. A. (1972), 'Sovetsko-francuzskoe sotrudnichestvo $\mathrm{v}$ kosmicheskih issledovaniyakh' [Soviet-French cooperation in space research], Vestnik AN SSSR, no. 11, pp. 84-92.

Grigorevskiy, V. M. (1967), 'Investigations based on photometric satellite tracking. Artificial Satellite Tracking: 1957-1967, transl. by J. Miller, Nablyudeniya Iskusstvennykh Sputnikov Zemli: 1957-1967, no. 6, pp. 1-60.

Grigorevsky, V. M. (1960), 'Izmeneniya perioda vrasheniya ISZ-2' [Changes in the rotation period of ISZ-2], Bull. AES, no. 8 (18), pp. 9-14.

Grigorevsky, V. M. (1961), 'O bystryh izmeneniyah perioda vrasheniya otnositelno poperechnoj osi vtorogo sovetskogo ISZ' [On rapid changes in the rotation period relative to the transverse axis of the second Soviet satellite], Doklady AN SSSR, vol. 137 , no. 3 , pp. 572-575.

Grigorevsky, V. M. \& Bukhbinder, M. A. (1967), 'Ob opredelenii plotnosti zemnoj atmosfery po tormozheniyu vrasheniya sputnika' [On determining the density of the Earth's atmosphere by slowing down the rotation of a satellite], in Nablyudeniya iskusstv, sputnikov Zemli, Bukharest: Izd-vo AN RSR, no. 5, pp. 155-159.

Grigorevsky, V. M.; Shmelev, G. M. \& Shmeleva, N. S. (1973), 'O nekotoryh sluchayah dvizheniya sputnikov v magnitnom pole Zemli' [About some cases of satellite motion in the Earth's magnetic field], Problemy kosmicheskoj fiziki, vol. 8, pp. 34-43.

Hrushytska, I. B. (2018), 'Stanovlennia fotometrychnykh doslidzhen shtuchnykh suputnykiv Zemli v Ukraini' [Formation of photometric studies of artificial satellites of the Earth in Ukraine], Eminak, vol. 2, no. 2(22), pp. 143-148. 
Hrushytska, I. (2019), 'The life and scientific activity of Ukrainian astronomer V. M. Grigorevsky (1930-1981)', History of Science and Technology, vol. 9, no. 2(15), pp. 147-159. https://doi.org/10.32703/2415-7422-2019-9-2(15)-147-159

'Kak my uchilis...' (2002), 'Kak my uchilis raspoznavat kosmicheskie obekty' [How we learned to recognize space objects], Vozdushno-kosmicheskaya oborona, no. 4. Retrieved from http://militaryarticle.ru/voenno-kosmicheskaya-oborona/2002-vko/12166-kakmy-uchilis-raspoznavat-kosmicheskie-obekty [accessed 15 Aug 2019]

Karetnikov, V. H. (2005), 'Hryhorevskyi Vitalii Mykhailovych' [Vitaly Mikhailovich Grigorevsky], in V. A. Smyntyna (ed.), Profesory Odeskoho (Novorosiiskoho) universytetu: biohrafichnyi slovnyk: $v 4$ t., vol. 2, 2nd ed., Odessa: Astroprynt, pp. 347-350.

Kasimenko, T. V. \& Lurie, M. A. (1965), 'Soveshanie nabliudatelei iskusstvennkyh sputnikov Zemli sostoyalos 1-5 fevralya v Rige' [The meeting of observers of artificial Earth satellites was held on February 1-5 in Riga], Vestnik AN SSSR, no. 6, pp. 94-95.

King-Hele, D. (1963), Iskusstvennye sputniki i nauchnye issledovaniya [Artificial satellites and scientific research], transl. by N. P. Slovokhotova, ed. by A. G. Masevich, Moscow : Izd-vo inostr. lit.

King-Hele, D. (1968), Nablyudaya sputniki Zemli [Observing Earth satellites], transl. by N. P. Slovokhotova \& V. E. Chertopruda, ed. by A. G. Masevich, Moscow: Mir.

Mandel, O. E. (1995), 'Professor V.M. Grigorevskij i issledovaniya ISZ' [Professor V. M. Grigorevsky and AES research], in V. G. Karetnikov (ed.) Stranicy istorii astronomii $v$ Odesse: sb. st., Part 2, pp. 53-58.

Masevich, A. G. (1959), 'Astronomicheskie nablyudeniya iskusstvennyh sputnikov Zemli' [Astronomical observations of artificial Earth satellites], Vestnik AN SSSR, no. 5, pp. 85-94.

Masevich, A. G. \& Lozinsky, A. M. (1970), 'Sovershenstvovanie sredstv izucheniya Vselennoj. Novye sovetskie kamery dlya fotonablyudenij iskusstvennyh nebesnyh tel' [Improving the means of studying the universe. New Soviet cameras for photo surveillance of artificial celestial bodies], Vestnik AN SSSR, no. 9, pp. 38-44.

Masevich, A. G. \& Slovokhotova, N. P. (1967), 'Ten years of international cooperation in the field of optical tracking of artificial Earth satellites, Artificial Satellite Tracking: 1957-1967', transl. by J. Miller, Nablyudeniya Iskusstvennykh Sputnikov Zemli: 1957-1967, no. 6, pp. 1-60.

Petrov, B. N. \& Kroshkin, M. G. (1972), 'Kosmicheskaya fizika i sotrudnichestvo uchyonyh socialisticheskih stran' [Space physics and the collaboration of scientists from socialist countries], Vestnik AN SSSR, no. 4, pp. 76-84.

Shmelev, G. M.; Grigorevsky, V. M. \& Shmeleva N. S. (1969), 'Vliyanie magnitnogo polya Zemli na kharakter dvizheniya sputnikov' [The effect of the Earth's magnetic field on the nature of satellite motion], Byul. st. optich. nablyudeniya iskusstv. sputnikov Zemli, no. 54, pp. 35-38. 
Slovokhotova, N. P. (1967), 'Soveshanie Komissii po mnogostoronnemu sotrudnichestvu mezhdu akademiyami nauk socialisticheskikh stran po probleme "Nauchnye issledovaniya s pomoshyu nablyudenij iskusstvennykh sputnikov Zemli"' [Meeting of the Commission on Multilateral Cooperation between the Academies of Sciences of the Socialist Countries on the issue "Scientific research using observations of artificial Earth satellites"], Vestnik Akademii nauk SSSR, no. 8, pp. 98-99.

Smith, D. E.; Beletsky, V. V.; Grigorevsky, V. M.; King-Hele, D. G.; Kissel, K. E. et al. (1970), 'The scientific uses of photometric observations of satellites-past and current research,' COSPAR Information Bulletin, no. 56, pp. 70-85.

State Archives of Odessa Region, Otchety sotrudnikov universiteta (1970) [Reports of university employees on foreign business trips (1970), F. p-1438.14.201, p. 141.

Sukhoterina, L. I.; Yampolsky, Y. S \& Bondar, V. I. (2013), 'Deiaki aspekty rozvytku kosmichnogo pryladobuduvannia v Ukraini (70-90-ti roky XX stolittia) [Some aspects of the development of space instrumentation in Ukraine (1970s-1990s)], Istoriia nauky i tekhniky, vol. 3, no. 3, pp. 136-142.

Tovadrovs, M. Ya.; Bagkhos, B. B.; Asaad, A. S. \& Grigorevsky, V. M. (1970), 'O tormozhenii sputnika posle solnechnoj vspyshki' [On satellite deceleration after a solar flare], Byul. st optich. nablyudeniya iskusstvennyh sputnikov Zemli, no. 57, pp. 47-53.

Iryna Hrushytska, Candidate of Historical Sciences, works at Odessa National Polytechnic University. In 1995, she graduated from Odessa State University named after I. Mechnikov with a degree in history. In 2015, she defended her PhD thesis in the field of history of science and technology at the Center for Scientific and Technological Potential and History of Science named after $\mathrm{G}$. M. Dobrov of the National Academy of Sciences of Ukraine, Kyiv. 